\title{
Quantitative Measurement of Antibody Inhibiting Reverse Transcriptase Activity in Cats Naturally Infected with Feline Immunodeficiency Virus
}

\author{
Takayuki SAITO, Kazuo SUZUKI*, Mitsunobu IMAI, and Yuji INABA ${ }^{1)}$ \\ Department of Virology, Kanagawa Prefectural Public Health Laboratory, 1-1-1 Nakao, Asahi-ku, Yokohama 241, and ${ }^{1)}$ Department of \\ Veterinary Epizootiology, College of Bioresource Sciences, Nihon University, 1866 Kameino, Fujisawa 252, Japan \\ (Received 4 March 1997/Accepted 22 May 1997)
}

ABSTRACT. Quantitative measurement of reverse transcriptase-inhibiting (RTI) antibodies in Japanese household cats naturally infected with feline immunodeficiency virus (FIV) was performed by poly A-linked colorimetric reverse transcriptase assay (PAC-RTA). Eight FIV-seropositive plasma samples were diluted twofold from 1:10 to 1:160 and incubated with FIV RT. Fifty percent RTI activity (RTI ${ }_{50}$ ) was calculated from a dose response PAC-RTA curve. The plasma of FIV-seropositive cats showed different RTI activities against two Japanese isolates and Petaluma strain. Six of eight plasma samples showed RTI activities against the Japanese isolates (subtype B), but only one showed RTI activity against Petaluma strain (subtype A). It is important to use the appropriate strain as a source of RT for detection of RTI antibodies in cats. - KEY wORDS: feline immunodeficiency virus, reverse transcriptase assay, RT-inhibiting antibody. J. Vet. Med.Sci. 59(9): 841-843, 1997

Feline immunodeficiency virus (FIV) causes an acquired immunodeficiency syndrome (AIDS)-like disease in cats that is clinically similar to AIDS in humans [8]. The properties of FIV reverse transcriptase (RT) are very similar to the human immunodeficiency virus (HIV) RT in the template specificity and the requirements for $\mathrm{Mg}^{2+}$ [6]. The sera of cattle [14], cats [2] and humans [11] naturally infected with retroviruses contain antibodies that inhibit RT activity. Fevereiro et al. [1] reported the presence of RT-inhibiting (RTI) antibodies in cats experimentally infected with FIV. They suggested that RTI antibodies may be useful in determining the approximate time of virus infection and as a marker for disease progression. We used the poly Alinked colorimetric reverse transcriptase assay (PAC-RTA) described by Suzuki et al. [13] for measurement of RTI antibodies in human infected with HIV [9]. Our data obtained by PAC-RTA were useful as a marker of disease progression. Then we applied the PAC-RTA for quantitative measurement of RTI antibodies in cats naturally infected with FIV.

Plasma samples of Japanese household cats were obtained from eight FIV-seropositive and three FIV-seronegative cats. These samples were tested by enzyme-linked immunosorbent assay (ELISA) (Pet Check, IDEXX Corp., Portland, Maine, U.S.A.) and by indirect immunofluorescence assay [4].

As the source of FIV RTs, two Japanese FIV isolates (TM1 and TM2 strains) [4] and an U.S. FIV isolate (Petaluma strain) [15] were used. The culture supernatants of MYA-1 cells (feline T-lymphoblastoid cells) [5] infected with each of the two Japanese isolates and the Petaluma strain were used for the assay.

The PAC-RTA was performed by the method of Suzuki et al. [13] with slight modifications [9]. Briefly, poly A was

\footnotetext{
* Present address: Suzuki, K., HIV Serology Laboratory, St. Vincent's Hospital, University of New South Wales, Sydney, NSW 2010, Australia.
}

solidified to microtiter plate. After the wells were washed three times with wash buffer $(10 \mathrm{mM}$ Tris- $\mathrm{HCl} \mathrm{pH} 7.5,0.15$ $\mathrm{M} \mathrm{NaCl}, 1 \mathrm{mM}$ EDTA and $0.01 \%$ Tween 20), $10 \mu \mathrm{l}$ of the supernatant from the FIV culture was added to each well with $50 \mu l$ of reaction buffer $(4.2 \mu \mathrm{M}$ biotin-dUTP, $8.4 \mu \mathrm{M}$ TTP, $25 \mathrm{mM} \mathrm{KCl}, 6.25 \mathrm{mM} \mathrm{MgCl}{ }_{2} 62.5 \mathrm{mM}$ Tris $\mathrm{pH} 7.8$, $1.25 \mathrm{mM}$ dithiothreitol and $2.5 \mu \mathrm{g} / \mathrm{m} l$ oligo $\left.\mathrm{dT}_{12-18}\right)$. The plate was incubated at $37^{\circ} \mathrm{C}$ for $15 \mathrm{hr}$ and washed with the wash buffer. Then $100 \mu l$ of horseradish peroxidase conjugated streptavidin diluted 1:5,000 in Tris-buffered saline with EDTA (TBSE) buffer (10mM Tris pH 7.5, 0.15 $\mathrm{M} \mathrm{NaCl}, 1 \mathrm{mM}$ EDTA and 1\% BSA) was added to each well. After the plate was incubated for $20 \mathrm{~min}$ at $37^{\circ} \mathrm{C}$, the free conjugate was removed by washing four times with the wash buffer. As a final step, $50 \mu l$ of 3,3',5,5'tetramethylbenzidine was added to each well. The plate was incubated at room temperature for $15 \mathrm{~min}$. The reactions were stopped by the addition of $50 \mu l$ of $1 \mathrm{~N}$ $\mathrm{H}_{2} \mathrm{SO}_{4}$. The plate was read at $450 \mathrm{~nm}$ with a plate reader.

Detection of RTI antibody in plasma was performed as follows; FIV RT in $50 \mu l$ of the reaction buffer adjusted to give an optical density of approximately 1.0 by PAC-RTA was added to each microtiter well with solidified poly A. Test plasma samples were diluted twofold from 1:10 to 1:160 with phosphate-buffered saline (PBS). Ten $\mu l$ of diluted plasma were added to each well containing FIV RT. After incubation for $15 \mathrm{hr}$ at $37^{\circ} \mathrm{C}$, RT activity was measured by PAC-RTA. The percentage of RT inhibition is defined as [1 - (RT activity with plasma/control RT activity with $\mathrm{PBS})] \times 100$.

Figure 1 shows the dose response curves of PAC-RTA against the RT of FIV TM1 strain starting from 1:10 to 1:160 dilutions of a FIV-seropositive (F001) and a FIVseronegative (F100) plasma. The curve for the FIV-seropositive plasma showed a significant inhibition of TM1 RT activity and an inverse relationship between percent inhibition and plasma dilution. The 73.3, 57.1, 43.2, 25.8 and 9.7 percent inhibitions were found at 1:10, 1:20, 1:40, $1: 80$ and $1: 160$ dilution, respectively. No significant 


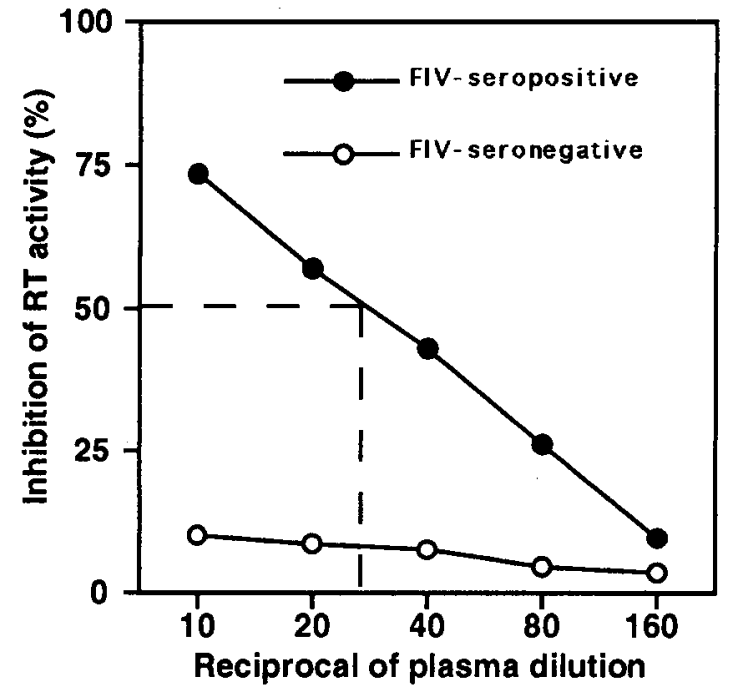

Fig. 1. Quantitative measurement of RTI antibody in a FIV seronegative and a FIV seropositive plasma. Antibody response curves of each plasma against FIV RT of the TM1 strain were obtained by PAC-RTA.

inhibition of FIV TM1 RT activity (10.1\% at 1:10 dilution) was observed with the FIV-seronegative plasma. From this figure, 50\% RT inhibition of FIV-seropositive plasma was calculated to be 1:30.2 dilution and its 50\% RTI activity $\left(\mathrm{RTI}_{50}\right)$ was expressed as its reciprocal, i.e., 30.2.

Based on this assay, the $\mathrm{RTI}_{50}$ values for eight FIVseropositive cats were determined against the two Japanese isolates (TM1 and TM2 strains) and the Petaluma strain. Plasma of three FIV-seronegative healthy cats, a HIV-1seropositive asymptomatic carrier human and a HIV-1-seronegative healthy human were also measured as negative controls. These results are shown in Table 1.

Six of eight FIV-seropositive plasma (F001, 002, 003, 004, 005 and 007) showed significant 50\% RTI activities against both Japanese FIV isolates, TM1 $\left(\mathrm{RTI}_{50}=12.4-37.1\right)$ and TM2 strains $\left(\mathrm{RTI}_{50}=15.6-66.4\right)$. Two others (F006 and F008) failed to inhibit the RT activities more than $50 \%$ at any dilutions against both Japanese FIV isolates. On the other hand, only one FIV-seropositive plasma (F003) showed 50\% RTI activity against the Petaluma strain $\left(\mathrm{RTI}_{50}=16.0\right)$, but the value of $\mathrm{RTI}_{50}$ was lower than that for TM1 $\left(\mathrm{RTI}_{50}=36.9\right)$ and TM2 $\left(\mathrm{RTI}_{50}=51.2\right)$. Three FIVseronegative, a HIV-1-seropositive and a HIV-1seronegative plasma did not show any RTI activity.

Fevereiro et al. [1] reported that eight out of nine cats experimentally infected with FIV produced RTI antibodies against FIV RT, and their relative titers increased over time. Significant concentrations of RTI antibodies were maintained for one to two years after infection, however these antibodies declined with the onset of clinical disease [1]. We also demonstrated that $\mathrm{RTI}_{50}$ in the patients infected with HIV decreased and became undetectable with disease progression [9]. Therefore, one of the explanation for the
Table 1. Detection of reverse transcriptase-inhibiting antibody in plasma

\begin{tabular}{llcl}
\hline \multirow{2}{*}{ Plasma } & \multicolumn{3}{c}{ Source of FIV RT } \\
\cline { 2 - 4 } & TM1 & TM2 & Petaluma \\
\hline FIV-positive & & & \\
F001 & $30.2 *$ & 28.7 & $<10$ \\
F002 & 15.0 & 15.6 & $<10$ \\
F003 & 36.9 & 51.2 & 16.0 \\
F004 & 12.4 & 20.7 & $<10$ \\
F005 & 20.0 & 21.2 & $<10$ \\
F006 & $<10$ & $<10$ & $<10$ \\
F007 & 37.1 & 66.4 & $<10$ \\
F008 & $<10$ & $<10$ & $<10$ \\
FIV-negative & & & \\
F100 & $<10$ & $<10$ & $<10$ \\
F101 & $<10$ & $<10$ & $<10$ \\
F102 & $<10$ & $<10$ & $<10$ \\
HIV-positive & $<10$ & $<10$ & $<10$ \\
HIV-negative & $<10$ & $<10$ & $<10$ \\
\hline
\end{tabular}

* $\mathrm{RTI}_{50}(50 \% \mathrm{RT}$ inhibiting activity was expressed as reciprocal of plasma dilution).

two FIV-seropositive cats without showing any detectable $\mathrm{RTI}_{50}$ titer is that these cats were at early stage of FIV infection or symptomatic phase at the time of sampling.

On the other hand, we found that the RTI antibodies in Japanese cats inhibited RT activities of the Japanese isolates rather than the Petaluma strain. FIV isolates have been classified into five subtypes (A, B, C, D and E) based on the sequence of FIV env gene [3, 7, 12]. The TM1 and TM2 isolates and the Petaluma strain were classified into subtype $\mathrm{B}$ and $\mathrm{A}$, respectively. Therefore, it might be possible that the RTI antibody of each cat has a different affinity to RT molecules derived from the FIV subtypes A and B. If it is true, another explanation for the failure of detection of RTI antibodies in the two cats could be given that the cats were infected with the other subtypes $(C, D$ and E). To answer this issue, further studies for reactivities of RTI antibodies against the other subtypes (C, D and E) are greatly required. Moreover, this implies the importance to use the appropriate strain as a source of RT for detection of RTI antibodies in cats naturally infected with FIV.

PAC-RTA used in this study is suitable for measuring a large number of samples at one time, it may provide a useful method for the study of FIV RTI antibodies.

ACKNOWLEDGMENTS. We are grateful to Dr. T. Mikami (The University of Tokyo, Tokoyo, Japan) for providing the FIV TM1 and TM2 strains and MYA-1 cell line. We also thank Dr. J. K. Yamamoto (University of Florida, U.S.A.) for providing the FIV Petaluma strain through Dr. H. Koyama (Kitasato University, Towada, Japan). We wish to thank the staff of the Department of Virology, Kanagawa Prefectural Public Health Laboratory, for their help and private animal hospitals in Tokyo for providing the blood of cats. 


\section{REFERENCES}

1. Fevereiro, M., Roneker, C., and De Noronha, F. 1991. Viral Immunol. 4: 225-235.

2. Jacquemin, P. C., Saxinger, C., Gallo, R. C., Hardy, W. D. Jr., and Essex, M. 1978. Virology 91: 472-476.

3. Kakinuma, S., Motokawa, K., Hohdatsu, T., Yamamoto, J. K., Koyama, H., and Hashimoto, H. 1995. J. Virol. 69: 36393646.

4. Miyazawa, T., Furuya, T., Itagaki, S., Tohya, Y., Nakano, K., Takahashi, E., and Mikami, T. 1989. Arch. Virol. 108: 59-68.

5. Miyazawa, T., Furuya, T., Itagaki, S., Tohya, Y., Takahashi, E., and Mikami, T. 1989. Arch. Virol. 108: 131-135.

6. North, T. W., Cronn, R. C., Remington, K. M., Tandberg, R. T., and Judd, R. C. 1990. J. Biol. Chem. 265: 5121-5128.

7. Pecoraro, M. R., Tomonaga, K., Miyazawa, T., Kawaguchi, Y., Sugita, S., Tohya, Y., Kai, T., Etcheverrigaray, M. E., and Mikami, T. 1996. J. Gen. Virol. 77: 2031-2035.

8. Pedersen, N. C., Ho, E. W., Brown, M. L., and Yamamoto, J.
K. 1987. Science 235: 790-793.

9. Saito, T., Suzuki, K., Ito, A., Hayashi, T., Watanabe, S., Kondo, M., and Imai, M. 1995. J. J. A. Inf. D. 69: 851-857 (in Japanese).

10. Saito, T., Suzuki, K., Imai, M., and Inaba, Y. 1997. J. Vet. Med. Sci. 59: 425-429.

11. Sano, K., Lee, M.H., Morales, F., Nishanian, P., Fahey, J., Detels, R., and Imagawa, D. T. 1987. J. Clin. Microbiol. 25: 2415-2417.

12. Sodora, D. L., Shpaer, E. G., Kitchell, B. E., Dow, S. W., Hoover, E. A., and Mullins, J. I. 1994. J. Virol. 68: 22302238.

13. Suzuki, K., Craddock, B. P., Okamoto, N., Kano, T., and Steigbiger, R. T. 1993. J. Virol. Methods 44: 189-198.

14. Wuu, K. D., Graves, D. C., and Ferrer, J. F. 1977. Cancer Res. 37: 1438-1442.

15. Yamamoto, J. K., Sparger, E., Ho, E. W., Anderson, P. R., O'Conner, T. P., Mandell, C. P., Lowenstine, L., Munn, R., and Pedersen, N. C. 1988. Am. J. Vet. Res. 49: 1246-1258. 